\title{
SERVICE TECHNOLOGIES CREATES A TANGIBLE LINK FOR VALUE GENERATION: SERVICE ECONOMY IN SRI LANKA
}

\section{SHYAMALIE EKANAYAKE AND DHAMMIKA ABEYSINGHE}

Department of Industrial Management, University of Kelaniya, Kelaniya , Sri Lanka.

E-mail: dhammi@kln.ac.lk

\begin{abstract}
A country's ability to develop a competitive service economy depends on its production sector, as they demand use of services. Continuous improvement or innovation in technologies in both manufacturing and services will simultaneously increase smooth flow of operations for competitiveness by lowering cost of production to enhance customer satisfaction, to attain value. The success of different industries depends on how well the service sector is geared to support them. To carry out better management strategies for value gain, it is necessary to provide a tangible link to integrate the production and distribution channels for efficiency and effectiveness of the organizational and technological dimensions. Technology transfer and continuous innovation of systems enhances productivity growth for cost competitiveness leading to better prices, responsiveness and flexibility of the processes to deliver a quality product to changing markets. The research purpose is therefore to identify management strategies and service technologies to analyze the characteristics of research variables in relation to GDP value generating sectors and focus on issues relating to value.
\end{abstract}

Key words: resources, service technology, integration, value.

\section{INTRODUCTION}

The service economy in Sri Lanka came into being to serve other sectors of the economy, i.e. agriculture and industry, and in turn agriculture and industry sustained 
the service function. The competitiveness of the service economy depended on availability of resources and their integration with technology to sustain the respective functions.

In Sri Lanka, the country's present economic value is attained through a diverse economic structure, having contributions from agriculture, industry and service sectors. The economic value is generated through free market policies governed by monetary and fiscal strategies. As announced by the Central Bank of Sri Lanka, the country's Gross Domestic Product (GDP) is US\$20.0 billion and population is calculated at 19.4 million in 2004, giving a per capita GDP of US\$ 1030 in 2004. Growth in real terms in 2004 was 5.4 percent. Compared to average world GDP growth rate at 4.1 percent in year 2004, Sri Lanka's achievement can be identified as a satisfactory attainment.

The country's present service structure emerged in two distinct phases; one with the sustained 'hydraulic civilization' with systematic application of science and technology to sustain irrigated agriculture system. Although there was hardly any marketable surplus, a mass of competitive capabilities including skills, know how, abilities of agronomical practices, irrigation and engineering were built centered around the tank with greater dependence on natural resources and preserving for future use. The emergence of the second phase began with plantation economy in 1850's. The service network expanded in parallel to the market demand of European buyers. Commercially, it was a buoyant period for Sri Lanka, as seen by large plantations, factories and manufacturing, work force and labour intensive practices. Banking and financial activities, transportation, insurance and other services were developed to facilitate foreign trade. Foreign exchange reserves enabled to carry out welfare systems.

Since independence, the economic expansion was largely due to market oriented policies, the emergence of the private sector with institutionalization of service arms such as banking and finance sectors, and more recently with the development of information communication technologies. The sustainability of the value generation deepened as structural transformation of resources as core competencies to fulfill the economic activities from production function (agriculture, industry) to distribution function. This has led ing to promotion and delivery process to the consumption function to attain value as market share and profitability, which in turn enhanced the standard of living leading to quality of life of people. Improvements are seen in real income, employment opportunities, health, education, housing, utility services, etc. 


\section{Research Problem}

Although these positive factors mentioned above are evident in the society, they are not seen as prosperous evidence in the current economic framework. The largest contributor to the present economy is the service sector, $56 \%$ share of GDP, surpassing agriculture and industry sectors with output, employment and labour productivity. The Central Bank Annual Report 2006 indicates that share of total imported supply of goods stands at $30 \%$, while total domestic supply of goods stands at $28 \%$, highlighting imported goods supply surpassing domestic goods supply. Moreover, existence of 'unfavourable' terms of trade highlighted by the rise in the growth rate in the imported goods unit price index in contrast to the approximately unchanged price of exports during the past years, as recorded by Central Bank of Sri Lanka.

The research problem therefore, focused here is that "in Sri Lanka, the economic development strategies used to harness resources are not achieving a greater value for the country". The problem studied here is 'what are the most suitable service strategies to harness resources to maximize value'?

\section{Research Objective}

Sri Lanka's dependence from sustained agriculture-export agriculture led economies has changed in significant proportions to an industrial and service based business economy in the last few decades. To identify core competencies and service technologies capable of value generation aligned with production function within the rapidly changing environment, therefore, is an important objective of this research.

\section{Literature Review}

A comprehensive literature survey was carried out to explore existing knowledge on research variables for development of a conceptual framework. In the identification of core competencies, Harvey \& Lusch (1997) have illustrated the importance of protecting core competencies of a company and refer them as an "amalgam of skills, resources, technologies and people" that make a company a leader in a specific area. Core competencies are composed of intangible assets that allow a company to effectively compete in market places and to differentiate itself from primary competitors. 
According to the literature survey there are useful elements capable of generating economic value. Ripple (1994) highlights that human creativity results through everyday problems in real-life situations and facilitated through educational interventions. Kaufman \& Kaufman's (2004) definition of creativity represent something different, new or innovative, useful and relevant. Lipsey \& Crystal (2004) explain that human have a free will and can behave in capricious ways.

Moreaux \& Ricci (2004) research highlights important characteristic of natural resources as "primary energy sources" and they are renewable and non-renewable. Stijns (2005) suggests that the ability of a country to exploit its resource base depends critically on the nature of the learning process involved. In terms of economic development, what matters most is what countries do with their natural resources and conclusion can be traced back to the type of learning process involved in exploiting and developing natural resources (Stijns, 2005).

An interpretation by Edvinsson \& Sullivan (1996) on human capital mentions that it is the collective experience, skills and general know-how of all firm's employees. It is a resource to generate value and difficult to deliver value without its employees. Leiponen (2005) says that the key role of human capital is innovation and policies needed to support R\&D with existing high levels of skills or supporting the development of complementary skills with innovative activities.

Edvinsson \& Sullivan (1996) explains business knowledge of two kinds; codified and tacit and highlights that this distinction is very important strategically. Balconi (2002) indicates that problem solvers and knowledge creators have become the key resources of the firms in the industrialized nations and process of automation and codification of technological knowledge involves increasing weight of fixed costs. It is profitable to develop comparative advantage than to spread resources along the value chain (Balconi, 2002).

Edvinsson \& Sullivan (1996) defines intellectual capital as knowledge that can be converted to value; Johannessen et al. (2005) describes it as an expression to denote all immaterial resources furthering value creation and has become a core competence in many business operations. Value creation is a result of mutual influencing process among technology, immaterial and material resources. Petrash (1996) depicts the formation of intellectual capital through integration of human capital, organizational capital and customer capital.

The Global Biodiversity Strategy (1992) identified many root causes for biodiversity crisis in all ecosystems. It was reported that economic systems and 
policies that fail to set proper value on the environment and natural resources and weaknesses in legal and institutional systems to have driven direct human impacts in the environment degradation. Ayyad et al. (2003) highlights the importance of ecological conservation and restoration as they have other economic values that have not been identified.

Some of the insights of empirical research on service technologies can be highlighted as ‘supplier/customer relationship' driven service technologies (Kanter, 1994), sustained innovation (Hardy \& Dougherty, 1997), delivering differentiation (Edwards, 1997), 'building seamless service structures' (Vandermerwe, 1994), identification of growth opportunities by R\&D-intensive firms (Lindell \& Karagozoglu, 1997).

\section{Conceptual Analysis}

The research study investigates the Sri Lankan context on GDP generating core components and identifies suitable management strategies to enhance value. The research proposes nine variables; 'human, 'natural resources', 'human capital', 'knowledge', 'capital', 'intellectual capital', 'GDP', 'incentives' and 'environment' considered as resource capabilities set in motion in an integrated process to create value. The research design identifies these variables as core competencies of the country and their combined efforts or cross functional activities are capable of generating value. To carry out better management strategies, it is necessary to provide a tangible link to integrate the production and distribution channels for efficiency and effectiveness of the organizational and technological dimensions. Technology transfer and continuous innovation of systems enhances productivity growth for cost competitiveness leading to better prices, responsiveness and flexibility of the processes to deliver a quality product to changing markets. The research purpose is therefore to analyze the characteristics of research variables in relation to GDP value generating sectors and focus to identify strategies relating to value.

\section{Research Methodology}

The research focus is value generation. The data collection for analysis of research problem was conducted among relevant decision makers/professionals belonging to state, public, private and international institutions who are responsible for creating strategies and managing value through resources and responsible for measurement systems. Data collection was carried out at policies/strategy making 
organizations for value generation, value generating industries and industry leaders, and value monitoring organizations in the country.

Due consideration was given to three GDP value generating sectors, namely, agriculture, industry and services in the selection process. The research was carried out through administering a questionnaire which had semi-structured, but, exploratory type questions to collect both data and ideas. In depth interviews were carried out to gather insight into current system and proposed system looking for appropriate management strategies. A questionnaire was used for personal interviews with preidentified individuals to access information.

Initially a pilot study was carried out covering 30 individuals from 23 organizations from agriculture, industry and service sectors to comply with the research data for the writing of this paper. The selection of organizations was mostly from Colombo (being the capital of Sri Lanka) as it is the focal point where policy makers, strategists and information for this type of research are concentrated in.

Out of the 23 institutions, 12 organizations were involved in service sector activities. They were identified as service organizations as they were creating value not through production process but by providing a service to the relevant field by promotional activities. Data collection effort gave more weight on bank, finance and IT sector as it was not feasible to cover all service sectors at this time. The research will continue for a larger sample of population. Although the limited research findings are not enough to make conclusions at this stage, we take this opportunity to present the findings as it is and it is illustrated in the section below.

\section{Management of Service Technologies}

The following resource variables (Table 1) were identified by focusing on country's resource strengths and its capabilities in the value generating process. In addition, research highlights the dimensions of service technologies required for manufacturing, distribution and consumption functions, and capable of building and strengthening long term competitive advantage of the value chain as illustrated below in Table 1 and discussed in detail in 'Discussion and Recommendations' section. 
Table 1: Management of Service Technologies to Enhance Resource Capabilities for Value Creation

\begin{tabular}{|c|c|c|c|}
\hline $\begin{array}{l}\text { Service Technologies } \\
\text { Creating the strategic link }\end{array}$ & $\begin{array}{l}\text { Resource } \\
\text { Variables }\end{array}$ & $\begin{array}{l}\text { Result Capable to } \\
\text { contribute to carry } \\
\text { value creating process } \\
\text { from one stage to } \\
\text { another }\end{array}$ & Result Measurement \\
\hline Education/training & human & Qualified people & $\begin{array}{l}\text { Qualifications, } \\
\text { employment/unemployment }\end{array}$ \\
\hline Skill development & human capital & Competencies & $\begin{array}{l}\text { Available skills, capabilities } \\
\text { and know how }\end{array}$ \\
\hline Learning process & natural resources & Energies & Types of energies used \\
\hline Build & knowledge & Knowledge transfer & Experts, entrepreneurs \\
\hline Invest & capital & Technologies & $\begin{array}{l}\text { Technologies, products and } \\
\text { services, service networks }\end{array}$ \\
\hline Commitment & intellectual capital & Market position & Markets and value \\
\hline $\begin{array}{l}\text { Policies and strategies to } \\
\text { employ researched resource } \\
\text { variables in value chain }\end{array}$ & GDP & Value/market share & Value and as a \% \\
\hline Re-invest & incentives & Restoration of value chain & Value \\
\hline Conservation / restoration & environment & Quality of life & GDP per capita \\
\hline
\end{tabular}

The research design identifies the above mentioned nine resource variables as core competencies of the country and their combined effort is capable of generating value. Potential for long term competitive advantage depends on building and nurturing these core competencies in the value creating process. The service technologies will provide:

i. Strategic resource link to integrate and maintain the resource capabilities to transform them from one stage to another in the value generating process.

ii. The service links will create tangible links to make it possible to carry out best management practices to attain value.

iii. Integration of service technologies and resources are expected to result enhanced capabilities to contribute to value generation. The capabilities are also 
measurable i.e. quality of life measured by GDP per capita income or else purchasing power parity.

The highly competing business environment is a creation of service technologies and continuous improvement is necessary for organizations to compete, retain their market position and stay ahead in competition. An important factor for consideration is that tangible management links have the potential to monitor progress, implement improvements, and to take corrective action to enhance the value creating process.

\section{DISCUSSION AND RECOMMENDATIONS}

The findings of the research are highlighted below in three separate areas; the service sector in Sri Lanka, resource requirements for the service economy and service sector output growth.

\section{The service sector of Sri Lanka}

Table 2 depicts growth rates during the years 2001 to 2005. The service sector carries the largest share of output growth, employment, and labour productivity rates in the economy. Productivity enhancement is an indication of utilization of modern production technologies in this sector.

Table 2. Sri Lanka economy's sectoral growth in output, employment and productivity

\begin{tabular}{|l|l|l|l|}
\hline Indicator & \multicolumn{1}{|c|}{$\mathbf{2 0 0 1}$} & \multicolumn{1}{|c|}{$\mathbf{2 0 0 4}$} & \multicolumn{1}{|c|}{$\mathbf{2 0 0 5}$} \\
\hline GDP output growth (percentage change) & -1.5 & 5.4 & 6.0 \\
\hline Unemployment rate (per cent of labor force) & 7.9 & 8.3 & 7.7 \\
\hline Sectoral classification of GDP (percentage change) & & & \\
Agriculture & -3.4 & -0.3 & 1.5 \\
Industry & -2.1 & 5.2 & 8.3 \\
Services & -0.5 & 7.6 & 6.4 \\
\hline Employment \% & & & \\
Agriculture & 32.4 & 34.1 & 30.7 \\
Industry & 25.1 & 21.4 & 24.5 \\
Services & 42.6 & 44.5 & 44.8 \\
\hline Labour Productivity, Rs. '000 per person & & & \\
Agriculture & 83.3 & 70.8 & 77.4 \\
Industry & 155.2 & 161.3 & 152.2 \\
\hline
\end{tabular}




\begin{tabular}{|l|l|l|l|}
\hline Services & 163.4 & 169.1 & 172.4 \\
& & & \\
\hline
\end{tabular}

Source: Central Bank of Sri Lanka, Annual Reports 2001, 2005.

The consumption function is the ultimate promotion and delivery process of the service industry, to create value. According to Central Bank of Sri Lanka Annual Report 2005, the total supply of goods and services at current prices, the share provided by domestic economic activities was 68 percent, while imports accounted 32 percent. The supply of domestic services 38 percent outperformed domestic goods at 30 percent. The value of trading activities, transport, communication, and financial services contributed significantly to the economic activities of the country.

Although a positive growth is seen in the service economy, the increasing public debt, budget deficit, increasing trade deficit and unemployment are country’s burdens. Preliminary findings from the Consumer Finances and Socio-economic Survey 2003/04 of the Central Bank indicate that historical and continuing regional disparities among the three sectors, Urban, Rural and Estate are evident, address these disparities and create economic and income generating opportunities all over the country would provide options for the citizens, and emphasizes that it is up to the citizens to make use of those opportunities to improve their quality of life (Bandaranaike, 2004).

The effects of globalization and liberalization policies have undoubtedly affected this sector in the areas of telecommunication, port, construction, financial services. The recent efforts on multilateral and bilateral trade liberalization policies are expected to increase competition further, and local service sectors should be geared to face these challenges.

\section{Resource requirements for the service economy:}

The findings administered by the research questionnaire described below under nine variables are considered as resource requirements to sustain the service function.

\section{Human}

The human component has a special responsibility in creating business/service strategies; three significant factors; one being there should be a product which relates to the market demand, output produced cost effectively and market networks for promotion and delivery for value gain in the present context. The immediate challenge 
of the human component is to craft strategies to override the challenges of international competition and source suitable technologies to access value.

Almost all service sector organizations interviewed said that they encourage 'employability security' endorsing Kanter's (1994) views, giving importance to education and training for skill development. In fact banking sector considers continuous training of employees as a strategy. Encouragement of creativity building is a necessity to look out for business opportunities. Mobility among the bank branch networks allows them exposure in different aspects of business. As a sizable budget is invested for training and development, they wish to retain the employees for longer term. IT companies recruit new entrants giving them practical experience to enhance their abilities to build innovations to find solutions.

\section{Natural resources}

According to NSF (2000), Sri Lanka's Natural resources include land, water, air, wetlands, forest, natural vegetation, varied natural ecosystems, man-made ecosystems, rich biodiversity, agricultural crops, domesticated animals, fish - both food fish and ornamental, clay and minerals specially gem stones.

A network of infrastructure across all geographic regions is essential to explore business opportunities and create connectivity. The distribution function of service organizations depend on diversified energy sectors. The primary economic infrastructures in the country which are telecommunication, transport, hotels, electricity, and water supply depend on energy sources such as water, petroleum, gas which are derived out of natural resources for survival. Major energy sources are petroleum, biomass, and hydroelectricity. The production and service technologies are linked to the hydroelectricity and biomass production function, and petroleum transfer is only linked to the distribution and consumption functions. As petroleum would become a scarce resource in the future, a long term strategy for learning, exploration and development of alternate energy sources such as coal power, renewable energy sources such as wind power, solar power, and hydropower are important considerations.

The eco tourism coupled with traditional historical heritage and biodiversity has evolved as a tourism industry. Customer oriented technologies are built targeting tourism including national carrier Sri Lankan airlines, transport services, hotels etc. Branded niche hotels such like "Elephant Corridor" located in an area where most number of elephants could be seen, "Kandalama Hotel” giving a glimpse of traditional 
culture amidst a temple, lake and habitat, "Tea Factory" hotel, a refurbished real tea factory in the middle of a tea plantation are some of niche hotels operating in Sri Lanka, catering to tastes of global market.

The gem industry is another high value industry based on natural resources having the capacity and capability to diversify service technologies for product differentiation to cater to different needs of consumers.

The 1988 National Conservation Strategy introduced by the Ministry of Environment and Natural Resources and Environmental Action Plan in 1992 provides a legal and institutional framework to address issues relating to sustainable development. The development strategy integrates different sectors to formulate proposals for action and monitor progress. The objective is to maintain a balanced environment, limit the increasing demands by the growing population on the island's limited resources and to pursue economic development. Those development sectors including sectors of service economy are also grouped as follows:

- Forestry and wildlife conservation

- Agriculture, plantations, land development and mining

- Fisheries, coastal and marine area management

- Industry and tourism

- Energy and transport

- Health, sanitation and urban development

\section{Human capital}

The human capital embodied with skills, knowledge and capability to solve problems are the main contributors of economic value creation. The key role of human capital is innovation. Their ability to develop and exploit new knowledge and knowledge transfer are requirements for innovation.

Sri Lankan framework on human capital concentrations woven together with skills, abilities and knowledge mostly associates with traditional to value added industrial sectors and service sectors. i.e. ceramic, gem, banking and finance, insurance, construction, tourism industries. New concepts and breakthrough technologies are now emerging in banks, apparel, telecommunication and IT industries, and they learn to work with 'seamless networks' to truly service customers. Here the companies expect to change the traditional thinking to bring out a new culture, mindset and attitude. The competitive telecommunication network made it possible for interaction and relationships to extend personalized services. The traditional as well as 
new skills, abilities and know-how are being transferred from one phase to another. i.e. skill of managing a labour force or human resources have been transferred from plantation sector to the industrial and later to the service sectors. A high demand for skilled human capital exists within the service sector. The transfers linked to high wage rates offered to skilled human capital, in similar disciplines takes place in a brisk atmosphere especially in IT, apparel, banks, finance and insurance fields. Customer satisfaction, producing goods on a timely basis, quality control, gaining customer loyalty, networking, collaborating are some of the abilities that are transferable among different economy sectors. The Board of Investment (BOI) managed industrial parks established under the government industrialization strategy promote employment with diverse skills, abilities and know-how. The finance and leasing companies value “instant judgment' capability of human capital in a highly competitive business sphere. The organizational network comprising of number of branches have 'delegated authority' to the officials enabling them to make on-the-spot decisions to acquire value. The finance, leasing and insurance companies, therefore, expect the new entrants to be experienced human capital.

Currently the private sector has come forward in consequence with market signals for marketing, finance, information technology training and skill development. The government sponsored Vocational Training Institute, Clothing Design Degree from University of Moratuwa and private sector managed Phoenix College of Clothing Technology, Chartered Institute of Marketing, Chartered Institute of Management Accountants are skill development and knowledge transfer institutions that had come up to serve the industries.

Individual incentives for skill development largely depend on the wage structure. The policies for skill development should be in parallel to the importance of economic activities and their contribution. More commitment and involvement is expected from human capital in network driven swift working environment. Sri Lanka Telecom (SLT) extending a voluntary retirement scheme (VRS) to its excess employees and introducing 'breakthrough thinking' concept in a problem solving paradigm in enhancing efficient, effective, market sensitive and customer focus views with extensive use of IT and other technologies have led to promote profit and performance driven culture. SLT's efforts are reflected in the increasing productivity levels as measured by the number of fixed telephone lines per employee. Fixed telephone lines per employee of 38 in 1996 have increased to 130 in 2005. 


\section{Knowledge}

Traditional knowledge built on clusters of economic activities developed competitive capabilities in skills and knowledge to produce output are the leftovers amidst the changing economic policies leading to investment crisis. The effective skills integrated with knowledge and skill transfer to resources have progressed as output.

The proper judgment is a result of accumulated knowledge and knowledge transfer. Knowledge makes decision making process easy. The knowledge in specialized areas is a requisite to decide faster. The function of networks require human to act and react with speed, ease and transfer. In a competitive homogeneous product market such as banks or finance when it is not possible to compete with interest rates, the companies bent towards services and service technologies to capture the value through fast decision making process and high customized services.

IT companies consider knowledge as 'passive' and encourage inert to surface to find solution for service delivery.

\section{Capital}

Innovation requires efficient technology. Investment in technology and financial capability are two dimensions correlated to each other. The continuous budget deficits have been a drawback in the country to infuse technology. Government has endorsed the private sector as the "engine of growth" expecting to fill that vacuum of upgrading technologies.

The service economy beginning from telecommunication sector has invested heavily on customer innovative infrastructure and technologies. Central Bank of Sri Lanka Annual Report 2005 indicates that the reforms introduced since 1981 have made telecommunication one of the most liberal, competitive and fast growing infrastructure services in the country. Vigorous competition is seen among three fixed line operators, four mobile line operators, 32 external gateway operators, 29 data communication and internet service providers, four paging operators, two pay phone operators, and two trunk radio operators. Improved technology on external gateway operations has resulted in improved international connectivity and reduction of charges significantly.

The high literacy rate in the country has the potential to further develop information technology based services for overseas and domestic needs. The banking and finance sector has capitalized this strength and have strengthened their networks with customer oriented products to the market. The banks, finance and leasing companies, insurance, internet service providers, software developers have introduced 
innovative products beginning from credit cards, debit cards, internet cards, dial-up connections, e-mail services, different saving schemes, fixed/term deposit, foreign currency deposit, housing loans to reach all sectors of society from minors to senior citizens.

Internet service providers are compelled to function between two monopolies of telecommunication companies for information transfer and to assign space in the World Wide Web for internet web hosting on fee basis. The customers in turn rely on the service providers for customer oriented strength. Software developers provide solutions for different trades for efficiency in value added management function. These solutions are mostly provided in turn to service organizations, such as construction, leisure, retail for financial accounting, hotels, sales/inventories, payroll management etc.

Successful technological innovation depends not only on technological capability, but also on other critical human capabilities in the areas of manufacturing, marketing, organization, strategy planning, learning, and resources allocation. History has demonstrated that innovation related to agriculture and industry related processes has taken place with accumulation of both physical and financial capital including buildings, roads, plantations, factories, production processes, reservoirs, cultural sites, transport systems, among the traditional value creating systems in the economy. These systems are highly human intensive systems needing to be continuously upgraded. With free market policies and privatization, industries of paper, sugar, oils and fats, cement, ceramic lost its potential in the competition. However, introduction of state-ofart technologies and financial capital are evident in the newly developed service and industrial sectors, such as IT, apparel, construction and industries under BOI.

The regulatory environment should sustain economic growth, productivity growth and job creation. The traditional challenges faced by many governments were budget deficits, domestic financing which pushed interest rates and crowding out private investment. In response government curtailed productivity enhancing infrastructure development. The inflows of foreign aid, fund transfers had the tendency to appreciate real exchange rates.

\section{Intellectual capital}

Technological innovation capability is a core competence comprising different key areas such as, technology, production, process, knowledge, experiences and organizations. It is tacit and cannot be codified. To gain a competitive position in the 
market to be a "price maker" instead of a "price taker" requires committed intellectual capital consisting of core competencies giving ability to perform competitively to carve a place in the market. Codified intellectual assets such as patents, trade marks, brands are also sources of innovation that owners' commercializes.

The Intellectual Property system in Sri Lanka makes provisions relating to copyright, industrial designs, patents, marks, trade names and unfair competition, and provide for the better registration, control and administration of such rights. The research indicates that two thirds of the registered patents are related to international products and only one third relates to local products. With regard to trade marks, approximately $60 \%$ of registered marks relates to local products while the other $40 \%$ relates to international trade marks.

Intellectual capital is currently visible in organizations under service sector such as telecommunication, bank and finance. The telecommunication companies such as Sri Lanka Telecom (SLT), Mobitel (Pvt) Ltd., Dialog Telekom Ltd. operate with the combination of human, organizational and customer capital. Their brands, 'SLT', 'Mobitel', 'Dialog' are accepted norms and familiar in the society. Their telecommunication technologies have merged human and customer capital to accrue value. The spectrum management of Telecommunication Regulatory Commission is another example of merging intellectual capital where they regulate 'radio frequency spectrum allocation' to monitor information flow among the many telecommunication service providers of the country.

A competitive banking and finance sector development is seen in the country. An intense competition is seen among intellectual capital for market dominance with familiar brands, products and services. Twenty two licensed commercial banks with a branch network of 1405, 1695 service outlets, 7013 automated teller machines and 6542 electronic fund transfer facilities were in operation in year 2005. In addition to traditional banking facilities they have added phone banking, e-banking, credit cards, deposits and loan schemes to get closer to the consumer. Twenty eight registered finance companies in the country compete with lending and deposit activities. The total assets of the finance system in year 2005 was Rs. 3144.7 billion. (US\$1.00 = Rs. 104.6 for 2005).

\section{GDP}

The GDP is the market value of all-final goods and resources produced by normal residents as well as non-residents in the domestic territory of a country. The 
research information on service network confirms that not only they require human capital to be employed to achieve output, but other human dimensions such as knowledge and intellectual capital discussed earlier are crucial for business value gain.

Most service organizations in their visionary focus are not geared for GDP value creation, but profit maximization is their primary goal. The two fields that this research mostly concentrated in, bank, finance and ICT indicated they do not consciously craft strategies for GDP value growth, but indirectly contribute to the GDP growth through their customers. High GDP value increases per capita income. Increase in purchasing power will expand the demand for network services. The telecommunication companies can expand their cable systems to match the demand for telephones, especially mobile phones; banks can introduce innovative products for savings and deposits schemes, and finance companies could expand their lease portfolio, as all these sectors can be assured of rental repayments when per capita income is more.

\section{Incentives}

Reinvestment in terms of incentives to sustain the production processes consisting of human, natural resources, human capital, knowledge, capital, intellectual capital, and environment are essential to maintain a dynamic production, distribution and consumption process and will be the thrust of government's fiscal policy objective for GDP value generation. Government monetary and fiscal policies should entail domestic investment aligned with resources to increase value. Fiscal incentives offered for producing goods and services, fixed capital formation - in plant and equipment, exports of goods and non-factor services, to facilitate connectivity networks in transportation, travel, insurance, merchandise trade, etc. related to the product base are important considerations.

Fiscal incentives stimulate private investment and attract FDI. One such an example is product manufacturing companies under BOI framework, classified as 'thrust industry' are eligible to receive incentives such as tax holidays, concessionary taxes, import duty exemptions for capital goods and other raw material.

Ability of a government to provide better health care, education and infrastructure investment are crucial for modern economies. Improvement in health and longevity of workers increases productive capacity and education leads to advances in knowledge necessary to maintain quality of life of the society. Investment in infrastructure such as transportation and telecommunication networks provides connectivity necessary to carryout economic tasks of a country. Focus on sensitivity in 
human health and limitations in environment demands solutions for favorable environmental outcomes.

\section{Environment}

The local Ministry of Environment and Natural Resources in their policy report for 2003-2007, indicates that environment be 'conserved' and 'preserved' for sustainable use. The literature survey also highlights restoration of environment as an equally important criterion to retain biodiversity to maintain diverse economic values of the environment. National Productivity Secretariat's initiation of ' ${ }^{5 S}$ ', 'Kaizen' 'Total Quality Management (TQM)' system in a Sri Lankan hospital and intention of expanding to others; Industrial Development Ministerial promotion of environment friendly industries, cleaner production functions, and promoting ISO 14000 to industries, are the service functions under the auspices of the Ministry. The 1993 Industrial Pollution Management (IPM) strategy and action plan which advocates pollution prevention commenced under the support of Central Environment Authority (CEA) and expects private and public sector participation. The service sector organizations driven by technologies such as telecommunication, banks have a naturally environmental friendly manner of operation. Conservation and restoration of environment maintains a balance between economic development and utilization of resources to ensure long term sustainable development of the society. Awareness and education on natural disasters, solid waste disposal, and occupational safety are areas that require well defined policies on behalf of human safety and health.

\section{Service sector output growth}

Research data was collected in order to identify organizational objectives and what type of resources used by three sector economy. Out of the 23 organizations interviewed, 12 belonged to the service sector. The organizations which operate under the government auspices has a service orientation such as National Productivity Secretariat promoting economic growth and social stability through enhancement of productivity in the formal and informal sectors of the economy, Ministry of Environment and Natural Resources promoting the sound management of Sri Lanka's environment, Rubber Development Department developing all aspects of rubber

\footnotetext{
1 5S, Kaizen, TQM: the effect of these quality enhancement tools leads to less waste, better quality and faster lead times bringing out continuous improvement, finally making the organization more profitable and competitive in the market place.
} 
cultivation, particularly rubber smallholder sector, Sri Lanka Telecom wishing to lead Sri Lanka to become the hub of telecommunications in South Asia. They are not directly committed to GDP value creation, but, indirectly through their customer service network they contribute to value.

The policy makers craft strategies with the intention of GDP value creation taking into account all the resources discussed above. Out of the service organizations who were interviewed and whose core competencies are concentrated with human capital, physical and financial capital, knowledge, intellectual capital as resources do not target increase in GDP value, but, profit maximization as a primary goal. Value creating organizations who utilize all nine resources are objectively focused on GDP growth. Monitoring institutions' objectives are to collect the primary data for dissemination for the use of policy planners.

The following illustration in Table 3 indicates the organizational focus objective for GDP value generation. Out of 12 service organizations interviewed during data collection, only $17 \%$ organizations directly targeted GDP output through their core functions of the organization. The balance $83 \%$ organizational direct targets were not GDP output, but, they indirectly participated in value generation through their partners and customers. Banking and finance sectors objectives were to maximize deposits, savings, profit portfolios. Telecommunication service providers' target would be to provide the telecommunication requirements of the nation and external markets. Their strategies are based on consumer purchasing power. Higher purchasing power will generate more demand for their services; and assured payment of their rentals. Economic growth allows the service providers to expand their core competencies to achieve more profits. High GDP value stimulates service value.

The study findings indicate that organizations mobilize their core competencies to achieve organizational goals and thereby contribute to GDP value. It suggests that country's economic growth allows service providers to focus their strategies on consumer purchasing power and expand their core competencies to achieve more returns. Unlike service providers, other two economies namely agriculture and industry directly contribute to the GDP value by being in the goods transformation process.

Research data collection on focused strategy of organizations for GDP growth is illustrated in Tables 3 and 3.1. Table 3 illustrates service economy's focused strategy for 12 companies interviewed. Table 3.1 illustrates the focus strategy for all 23 companies interviewed so far. 
Table 3 : Service Economy's Focused Strategy for GDP Output Growth or not target GDP output growth

\begin{tabular}{|l|c|c|c|}
\hline No. of Organizations & Target GDP Output & Not target GDP Output & Total \\
\hline Organization No. & 2 & 10 & 12 \\
\hline Percentage of organizations & $17 \%$ & $83 \%$ & 100 \\
\hline
\end{tabular}

Table 3.1 : Focused Strategy for GDP Output Growth or not target GDP output growth

\begin{tabular}{|l|c|c|c|}
\hline No. of Organizations & Target GDP Output & Not target GDP Output & Total \\
\hline Organization No. & 11 & 12 & 23 \\
\hline Percentage of organizations & $48 \%$ & $52 \%$ & 100 \\
\hline
\end{tabular}

It was also necessary to learn organizational use of resources to achieve their objectives. It was revealed that not all the organizations use all nine resource variables to achieve their company objectives (as shown in Tables 4 and 4.1).

Table 4 depicts 12 service organizations usage of resources. Capital, human capital and intellectual capital were mostly used resources in service organizations.

Table 4 : $\quad$ Service Organizations usage of nine resources for value creation

\begin{tabular}{|l|c|}
\hline Resources & No. of organizations \\
\hline Human & 6 \\
\hline Natural Resources & 5 \\
\hline Human capital & 9 \\
\hline Knowledge & 8 \\
\hline Capital & 10 \\
\hline Intellectual capital & 9 \\
\hline Output & 4 \\
\hline Input & 7 \\
\hline Environment & 7 \\
\hline
\end{tabular}


Table 4.1. All Organizational usage of nine resources for value creation

\begin{tabular}{|l|c|}
\hline Resources & No. of organizations \\
\hline Human & 14 \\
\hline Natural Resources & 13 \\
\hline Human capital & 20 \\
\hline Knowledge & 18 \\
\hline Capital & 18 \\
\hline Intellectual capital & 17 \\
\hline Output & 12 \\
\hline Input & 15 \\
\hline Environment & 15 \\
\hline
\end{tabular}

Table 4.1 depicts all 23 organizations usage of 9 types of researched resources. Mostly used resource was human capital, knowledge and capital and least used resource was natural resources.

It is too early to analyze the information with a narrow sample of population. However, it revealed that mostly used resource among the organizations interviewed were 'human capital'. Agriculture sector and industry sector where data collection was possible utilized all nine resources to achieve their objectives, whereas the service sector according to the people interviewed mostly relied on human capital, knowledge, capital and intellectual capital to achieve their objectives, revealing a disintegration of resources from the main value chain to concentrate among few resources to achieve the organizational objectives. Further research is required on this situation with regard to value generation.

\section{CONCLUSION}

The research highlights two dimensions of service technologies in the value creating process. The integration of service technologies with resources creates the strategic link to transform resource capabilities for value generation. The continuous improvement in technologies will nurture the core competencies to sustain the longterm value creation process. Instead of service technologies working in isolation, they should be brought out to the mainstream by economic policy framework to integrate with resource capabilities for their competitive advantage. Education and training of 'human'; skill development of 'human capital'; linking learning process for 
exploration of 'natural resources'; transfer of 'knowledge'; investment in 'capital' for technologies; commitment of 'intellectual capital' to position the products in the markets; policies and strategies to enhance GDP value; and offer incentives to sustain production processes and conservation and restoration of environment finally, maintain a balance between the resources and its economic activities to bring out the enhanced value of market share and profitability leading to quality of life of people. The measurable resource capabilities allow the management function to be a tangible one.

The second dimension is the value of consumer purchasing power as a decisive factor for the service industry to craft strategies. As discussed earlier, consumer purchasing power or the ability to pay for the service they receive maintains the capability of the value chain and sustain the service function.

\section{REFERENCES}

Ayyad, M. A. 2003. Case studies in the conservation of biodiversity: degradation and threats. Journal of Arid Environment, 54, 165 - 182.

Balconi, M. 2002. Tacitness, codification of technological knowledge and the organization of industry. Research Policy 31 : 357-379.

Bandaranaike, A.D. 2004. Are life styles and living conditions in Sri Lanka changing? Preliminary findings from the consumer finance socio-economic survey 2003/2004. Occasional Paper No. 53, Central Bank of Sri Lanka, Colombo.

Economic Progress of Independent Sri Lanka, Central Bank of Sri Lanka, 1998.

Edwards, J. 1997. Delivering differentiation: Building winning enterprises. European Management Journal 15(1) : 79 - 91.

Edvinsson, L. \& P. Sullivan. 1996. Developing a model for managing intellectual capital. European Management Journal 14 (4) : 356 - 364.

Harvey, M. \& R. Lusch. 1997. Protecting the core competencies of a company: Intangible Asses Security. European Management Journal 15 (4), 370 - 380.

Hardy, C. \& D. Dougherty. 1997. Powering product innovation. European Management Journal 15(1) : $16-27$.

Johannessen, J. A., B. Olsen \& J. Olaisen. 2005. Intellectual capital as a holistic management philosophy: a theoretical perspective. International Journal of Information Management 25: 151 -171. 
Kelegame, S. \& G. Corea. 2004. Economic policy in Sri Lanka : Issues and debates, Sage Publication.

Kanter, R. M. 1994. Change in the global economy: An interview with Rosabeth Moss Kanter. European Management Journal 12(1) : 1 - 8.

Kaufman, J. C. \& A.B. Kaufman. 2004. Applying a creativity framework to animal cognition. New Ideas in Psychology 22 :143 - 155.

Lipsey, R. G. \& K.A. Chrystal. 2004. Economics, $10^{\text {th }}$ Ed. Oxford University Press, New Delhi.

Lindell, M. \& N. Karagozoglu. 1997. Global strategies for US and Scandinavian R\&D-Intensive small - and medium-sized companies. European Management Journal $15(1)$ : $92-100$.

Moreaux, M. \& F. Ricci. 2005. The simple analytics of developing resources from resources. Resource and Energy Economics 27 (1) : 41 - 63.

National Productivity Policy for Sri Lanka, Ministry of Employment and Labour.

NSF. 2000. Natural Resources of Sri Lanka, 2000. National Science Foundation, Sri Lanka.

Petrash, G.1 1996. Dow’s Journey to a Knowledge Value Management Culture. European Management Journal 14 (4) : 365 - 373.

Ripple, R. E. 1989. Ordinary Creativity. Contemporary Educational Psychology 14 (3) : 189-202 .

Stijns, J.P.C. 2005. Natural resource abundance and economic growth revisited. Resources Policy 30(2) : 107-130.

Sri Lanka Telecom Annual Report, 2005.

Vandermerwe, S. 1994. Building seamless service structures: Some whys, whats, hows. European Management Journal 12 (3) : 280 - 286. 